\title{
Efficacy of Metalaxyl, Fosetyl-Aluminum, and Straw Mulch for Control of Strawberry Leather Rot Caused by Phytophthora cactorum
}

\author{
M. A. Ellis, Professor, Department of Plant Pathology, The Ohio State University, The Ohio Agricultural Research \\ and Development Center, Wooster 44691; W. F. Wilcox, Associate Professor, New York State Agricultural Experi- \\ ment Station, Cornell University, Geneva 14456; and L. V. Madden, Professor, Department of Plant Pathology, The \\ Ohio State University, The Ohio Agricultural Research and Development Center
}

\begin{abstract}
Ellis, M. A., Wilcox, W. F., and Madden, L. V. 1998. Efficacy of metalaxyl, fosetyl-aluminum, and straw mulch for control of strawberry leather rot caused by Phytophthora cactorum. Plant Dis. 82:329-332.

Chemical and cultural controls for strawberry leather rot, caused by Phytophthora cactorum, were compared in replicated plots on a commercial farm near Wooster, Ohio. Straw mulch, applied uniformly for winter protection, was removed in early spring from between the rows of all check and fungicide treatment plots. Supplemental straw mulch was applied to other plots to achieve a level of approximately $9 \mathrm{t} / \mathrm{ha}$. Overhead irrigation, which caused the soil to puddle, was provided on alternate days during rain-free periods to promote disease development $(58,66$, and $73 \%$ incidence in check plots for 1993, 1994, and 1995, respectively). Foliar sprays of fosetyl-Al, applied weekly from bloom through preharvest at rates (a.i.) of 2.24 and $4.48 \mathrm{~kg} / \mathrm{ha}$, provided 88 to $96 \%$ control, with no significant difference between fungicide rates. Metalaxyl $(1.17 \mathrm{~kg} / \mathrm{ha})$, applied either once or twice as a soil drench from early growth through fruit set, provided 82 to $94 \%$ control. Straw mulch alone provided 95 to $99 \%$ control. Thus, straw mulch between the rows was equally or more effective than fungicides for controlling leather rot.
\end{abstract}

Leather rot of strawberries was first reported from the southern United States by Rose (12) in 1924, who also demonstrated that Phytophthora cactorum (Lebert \& Cohn) J. Schröt. is the causal agent. Since then, leather rot has been recognized in a number of different states, and is reported to be an important disease in Europe and parts of Asia $(2,4,5,14,17,18)$. Leather rot occurs only sporadically, but can potentially cause considerable damage. For instance, fruit losses of 20 to $30 \%$ were common in many commercial fields during a 1981 epidemic in Ohio, and some growers experienced a $50 \%$ crop loss (2). In addition to such direct damage, the disease can also cause indirect losses related to the pungent, unpleasant taste and odor of infected fruit. Unlike most other fruit rot diseases, symptoms of leather rot may be subtle on ripe fruit, which thus can be picked and consumed along with healthy fruit. Growers have experienced com-

Corresponding author: M. A. Ellis

E-mail: ellis.7@osu.edu

Salaries and research support provided by State and Federal funds appropriated to the Ohio Agricultural Research and Development Center, The Ohio State University, and the Ohio Vegetable and Small Fruit Research and Development Program. Manuscript number 83-97.

Accepted for publication 28 November 1997.

Publication no. D-1998-0113-01R

(C) 1998 The American Phytopathological Society plaints from customers about off-flavored jams and jellies after processing fruit from fields where leather rot was a problem (M. A. Ellis, unpublished data). Therefore, the tolerable incidence of leather rot is near zero, and some Midwestern growers have reported closing plantings to pick-yourown customers as soon as leather rot was detected.

Leather rot control requires a program that integrates the use of various cultural practices and effective fungicides when required (8). Perhaps the most important cultural practice is proper site selection or drainage improvement to reduce or eliminate standing water (5). A layer of straw mulch between the rows also reduces disease incidence $(7,10)$. Straw mulch affects leather rot epidemics by: preventing fruit from contacting infested soil; providing a barrier between fruit and freestanding water; and reducing the splashing of water droplets bearing zoospores or sporangia $(6,7)$. Cultural practices frequently are sufficient for effective control of leather rot (M. A. Ellis, unpublished data), but sometimes epidemics still occur, especially during wet years or on sites with marginal or poor drainage.

Prior to the relatively recent registrations of metalaxyl (Ridomil 2E) and fosetyl-Al (Aliette) for use on strawberries, there were no highly effective fungicides available in the United States for leather rot control. Although both metalaxyl and fosetyl-Al are known to be highly efficacious for control of Phytophthora spp. in general $(1,13)$, and are currently registered for leather rot control, little has been published on their efficacy for this use.

The purpose of this study was to compare the efficacy of straw mulch usage and various metalaxyl and fosetyl-Al programs for control of leather rot under field conditions.

\section{MATERIALS AND METHODS}

In 1993, research plots were established in a 3-year-old commercial planting of the cultivar "Allstar" near Wooster, Ohio. Plots (replications) consisted of three adjacent, 3-m-long rows with $0.9 \mathrm{~m}$ between rows. Treatments were replicated four times in a randomized complete block design. Plants were maintained in a matted-row system that was renovated annually (3). For winter protection, the planting was covered with approximately $9 \mathrm{t} / \mathrm{ha}$ of wheat straw in early December 1992. On 5 April, plants were uncovered and straw was moved to the area between the rows. On 19 April, straw was removed from between the rows of all plots except for those of one treatment designated to receive straw mulch between the rows plus foliar applications of fosetyl-Al. These plots received a supplemental straw application on 19 April to provide a total of approximately $9 \mathrm{t} / \mathrm{ha}$, and no bare soil was visible in them. Metalaxyl (as Ridomil 2E) and fosetyl-Al (as Aliette 80WDG) were applied at various times, in accordance with current label recommendations (Table 1), using a hand-held $\mathrm{CO}_{2}$ sprayer with a pressure of $276 \mathrm{kPa}$ and a water volume of 935 liters/ha. Metalaxyl was applied to the entire area of each treated plot at $1.17 \mathrm{~kg}$ a.i./ha on 29 April, then $13 \mathrm{~mm}$ of water was supplied immediately afterwards through overhead irrigation (spring drench treatment). This application was repeated at either $10 \%$ bloom or when green fruit became present. Fosetyl-Al was applied foliarly at weekly intervals from 14 May (10\% bloom) through 11 June (fruit turning red), at $2.24 \mathrm{~kg}$ a.i./ha in the straw-mulch plots and $4.48 \mathrm{~kg}$ a.i./ha in the bare-soil plots.

In order to insure disease development, plots were flooded using an overhead sprinkler every other day (unless rain occurred), from 18 May to 10 June (5 days before first harvest). Irrigation provided water at approximately $0.64 \mathrm{~cm} / \mathrm{h}$ and plots 
were watered for $2 \mathrm{~h}$ each time. All ripe and diseased fruit were harvested from each plot on 15, 18, and 22 June. The number of leather rot-infected and marketable fruit, and the total yield (weight) were recorded for each replication and harvest date.

The experiment was repeated in 1994, in a 2-year-old planting of the cultivar "Honeoye" on the same farm. Winter straw cover was removed from the field on 7 April. Plots were established as previously described and straw was removed from between the rows in all treatments except one on 21 April. This treatment consisted of a supplemented straw mulch only (9 $\mathrm{t} / \mathrm{ha}$ ), with no application of fungicide. Metalaxyl was applied as previously described as a spring drench only or as a single application at $10 \%$ bloom (Table 2). Fosetyl-Al was applied at 2.24 and 4.48 $\mathrm{kg} / \mathrm{ha}$ at weekly intervals from $10 \%$ bloom to 1 week before the first harvest. Plots were flooded every 2 days from 16 May to 5 June, as previously described. All fruit were harvested and data collected, as previously described, on 13, 17, and 20 June.

In 1995, the experiment was established in the same planting of Honeoye. Treat- ments were repeated as previously described, except that fosetyl-Al was applied at the $2.24 \mathrm{~kg} / \mathrm{ha}$ rate only at weekly intervals from $10 \%$ bloom to the green-fruit stage. Metalaxyl was applied as a spring drench only or at late bloom (Table 3). Plots were flooded from 18 May to 6 June, as previously described. Plots were harvested and data collected, as previously described, on 13, 16, and 21 June.

In all 3 years of testing, all plots received separate foliar applications of iprodione at $1.12 \mathrm{~kg}$ (a.i.)/ha for control of Botrytis cinerea fruit rot on the same dates that fosetyl-Al was applied.

Analysis of variance (ANOVA) was used to determine the effects of treatment on the percentage of fruit with leather rot symptoms, percentage of marketable fruit, and total yield. Transformations were used to stabilize variances. Duncan's modified (Bayesian) least significant difference test was used to separate means after ANOVA at $P=0.05$.

\section{RESULTS AND DISCUSSION}

Removing straw from between rows and repeatedly flooding test plots resulted in a 58 to $73 \%$ incidence of leather rot in the untreated control plots over the 3 years of the trial (Table 1-3). In each year, fungicide treatments reduced leather rot incidence by 82 to $98 \%$ relative to the untreated control, resulting in a greater percentage of marketable fruit and a greater total yield. Total yield effects probably resulted from the failure of infected immature fruit to increase in size.

In 1993, equivalent disease control was provided by all fungicide treatments (Table 1). Treatments in 1994 were designed to determine differences between two rates of fosetyl-Al (representing the highest and lowest labeled rates, respectively), a single application of metalaxyl at two different times, and the use of straw mulch alone. There was no difference between the fosetyl-Al rates with respect to leather rot incidence, percentage of marketable fruit, or total yield. Subsequent results in 1995, where the lower rate again provided excellent control under extreme disease pressure, is further evidence that this rate is adequate under the application regime used in our trials.

The United States label for Aliette directs that applications for leather rot con-

Table 1. Effect of fungicides and straw mulch on control of strawberry leather rot, 1993

\begin{tabular}{|c|c|c|c|c|c|}
\hline Treatment $^{v}$ & Rate (a.i./ha) & Timing & Leather rot $(\%)^{\mathrm{w}}$ & Marketable Fruit $(\%)^{x}$ & Total yield $(\mathbf{k g})^{y}$ \\
\hline Fosetyl-Al plus straw mulch & $2.24 \mathrm{~kg}$ & $\begin{array}{r}\text { Start } 10 \% \text { bloom then } 7 \text {-day } \\
\text { interval }(14,21,28 \text { May; } \\
4 \text { and } 11 \text { June })\end{array}$ & $3.6 b^{z}$ & $92.2 \mathrm{a}$ & $12.80 \mathrm{a}$ \\
\hline Fosetyl- Al & $4.48 \mathrm{~kg}$ & $\begin{array}{r}\text { Start } 10 \% \text { bloom then } 7 \text {-day } \\
\text { interval (14, } 21,28 \text { May; } \\
4 \text { and } 11 \text { June })\end{array}$ & $6.7 \mathrm{~b}$ & $88.3 \mathrm{a}$ & $10.40 \mathrm{~b}$ \\
\hline Metalaxyl & $1.17 \mathrm{~kg}$ & $\begin{array}{r}\text { Two applications } \\
\text { (i) Prebloom drench (29 April) } \\
\text { (ii) } 10 \% \text { bloom (17 May) }\end{array}$ & $6.4 \mathrm{~b}$ & $86.6 \mathrm{a}$ & $11.30 \mathrm{~b}$ \\
\hline Metalaxyl & $1.17 \mathrm{~kg}$ & $\begin{array}{r}\text { Two applications } \\
\text { (i) Prebloom drench (29 April) } \\
\text { (ii) Green fruit (26 May) }\end{array}$ & $8.1 \mathrm{~b}$ & $85.9 \mathrm{a}$ & $12.50 \mathrm{a}$ \\
\hline Untreated control & & & $58.0 \mathrm{a}$ & $37.6 \mathrm{~b}$ & $7.70 \mathrm{c}$ \\
\hline Least significant difference (LSD) & & & 6.9 & 6.8 & 0.98 \\
\hline
\end{tabular}

Table 2. Effect of fungicides and straw mulch on control of strawberry leather rot, 1994

\begin{tabular}{|c|c|c|c|c|c|}
\hline Treatment $^{v}$ & Rate (a.i./ha) & Timing & Leather rot $(\%)^{\mathrm{w}}$ & Marketable fruit $(\%)^{\mathrm{x}}$ & Total yield $(\mathbf{k g})^{\mathrm{y}}$ \\
\hline Fosetyl-Al & $2.24 \mathrm{~kg}$ & $\begin{array}{r}\text { Start } 10 \% \text { bloom then } 7 \text {-day } \\
\text { interval }(13,20,27 \text { May } \\
\text { and } 6 \text { June })\end{array}$ & $5.5 \mathrm{bc}^{\mathrm{z}}$ & 87.7. b & $6.7 \mathrm{a}$ \\
\hline Fosetyl-Al & $4.48 \mathrm{~kg}$ & $\begin{array}{r}\text { 7-day interval }(13,20,27 \text { May } \\
\text { and } 6 \text { June })\end{array}$ & $6.8 \mathrm{bc}$ & $90.4 \mathrm{ab}$ & $6.5 \mathrm{a}$ \\
\hline Metalaxyl & $1.17 \mathrm{~kg}$ & Prebloom drench (28 April) & $10.3 \mathrm{~b}$ & $85.2 \mathrm{~b}$ & $7.1 \mathrm{a}$ \\
\hline Metalaxyl & $1.17 \mathrm{~kg}$ & Drench 10\% bloom (19 May) & $4.1 \mathrm{bc}$ & $86.9 \mathrm{~b}$ & $7.8 \mathrm{a}$ \\
\hline Straw mulch only & & & $3.4 \mathrm{c}$ & $95.4 \mathrm{a}$ & $7.3 \mathrm{a}$ \\
\hline Untreated control & & & $65.9 \mathrm{a}$ & $23.4 \mathrm{c}$ & $4.8 \mathrm{~b}$ \\
\hline Least significant difference (LSD) & & & 6.8 & 6.5 & 1.6 \\
\hline
\end{tabular}

${ }^{\mathrm{v}}$ Fosetyl-Al applied as Aliette 80WDG and metalaxyl applied as Ridomil 2E, according to methods described in text.

${ }^{w}$ Mean percentage of Phytophthora cactorum-infected fruit from three harvest dates (13, 17, and 20 June).

${ }^{x}$ Mean percentage of marketable fruit from the above three harvest dates.

y Total yield from the above three harvest dates.

${ }^{\mathrm{z}}$ Numbers followed by the same letter within columns do not differ significantly according to Duncan's modified (Bayesian) LSD test $(P=0.05)$. 
trol should start at $10 \%$ bloom and continue at 7- to 14-day intervals as needed. With a 7-day spray interval and three to five seasonal applications, we thus followed a fairly intensive application program. However, the alternate-day irrigations that we imposed provided conditions that were extremely favorable for disease development and which may seldom, if ever, be encountered in a commercial strawberry planting. Additional tests using fewer applications at the longer (14-day) interval under environmental conditions less favorable for disease development are needed to determine the lowest level of this fungicide required to achieve acceptable disease control under typical agricultural conditions.

Timing of a second metalaxyl application did not influence the efficacy of a program that included a prebloom drench in 1993, nor was there a difference in 1994 between a single application timed before first bloom or 3 weeks later at $10 \%$ bloom (Table 2). In contrast, a prebloom application in 1995 provided more control than one at late bloom, which was less effective than any other treatment (Table 3). In 1995, leather rot developed extremely early, with approximately 5 to $6 \%$ of the immature fruit present showing disease symptoms at the time of the late-bloom application. Although this treatment greatly limited further disease development, it nevertheless resulted in higher disease incidence. Thus, it appears that metalaxyl should be applied no later than $10 \%$ bloom in seasons that are conducive to early leather rot development.

Metalaxyl is labeled for use in the early season (after the ground thaws but before first bloom) and it is commonly applied then in both Ohio and New York to control red stele, caused by Phytophthora fragariae Hickman var. fragariae (M. A. Ellis and W. F. Wilcox, personal observations). In our trials, a single prebloom application provided good control of leather rot, even without the supplemental application at fruit set allowed by the label. The efficacy of a single, early-season application for control of leather rot has not been reported previously. Fosetyl-Al is labeled for multiple applications beginning at early bloom, and sprays of other fungicides for control of gray mold (Botrytis cinerea Pers. ex Fr.) are also most effective when applied during bloom (16). Thus, fungicidal control of leather rot can be provided by an early season application of metalaxyl that also is targeted at red stele, and/or by tank-mixing fosetyl-Al with gray mold sprays during bloom. The need for and optimal timings of these applications could be assessed using a predictive system that identifies weather conditions favorable for leather rot development $(9,10)$. Because resistance to metalaxyl occurs readily, using it in alternation with an unrelated compound such as fosetyl-Al is one strategy for minimizing the threat of $P$. cactorum developing resistance to this fungicide (15).

The straw mulch treatment provided excellent results in both years that it was examined alone. This treatment resulted in less leather rot than the early season application of metalaxyl in 1994 (Table 2) or the late bloom application in 1995 (Table 3 ). That straw mulch would provide some control of leather rot was predictable based on the requirement of soilborne inoculum to contact fruit before initiating an epidemic, by previous research in the field, and from results with a rain simulator which showed that increasing surface roughness reduces splash dispersal of spores $(6,7,10)$. However, this is the first demonstration that straw mulch can provide control of leather rot that is at least equal to that of registered systemic fungicides. Recent work by Ristaino et al. (11) further demonstrates the strong effects of a cover crop or ground cover on disease caused by a similar splash-dispersed pathogen ( $P$. capsici Leonian) on pepper.

In addition to minimizing leather rot incidence, straw mulch also greatly improved the visual appearance of healthy fruit relative to those from the unmulched fungicide plots, most of which had some soil on their surface. In fact, the percentage of marketable fruit was higher in the straw mulch treatment than in three of the four fungicide treatments in 1994 (Table 2) and in two of the three fungicide treatments in 1995 (Table 3). Thus, straw mulch provides a physical barrier between strawberry fruit and soilborne inoculum of pathogens like $P$. cactorum; reduces splash dispersal of this organism and other pathogens (e.g., Colletotrichum spp.; 6), and helps to keep healthy fruit clean and attractive. We consider it an important, practical component of integrated pest management systems for strawberries, particularly in the perennial production systems of the Midwest and Northeast.

\section{LITERATURE CITED}

1. Chalandon, A., Crisinel, P., and Paviot, J. 1980. Utilisation du phosethyl Al (Aliette [R]) Pour la lutte le Phytophthora fragariae et le Phytophthora cactorum L. et C. due fraisier. Meded. Fac. Landbouwwet. Rijksuniv. Gent. 45:207-219.

2. Ellis, M. A., and Grove, G. G. 1983. Leather rot in Ohio strawberries. Plant Dis. 67:549.

3. Funt, R. C., Ellis, M. A., and Williams, R. N. 1985. Ohio Strawberry Production, Management, and Marketing Manual. Ohio State Univ. Ext. Bull. 436. The Ohio State University, Columbus.

4. Kao, C. W., and Lu, L. S. 1979. Strawberry fruit rot caused by Phytophthora cactorum and Phytophthora citrophthora. Plant Prot. Bull. Taipei 21:239-243.

5. Maas, J. L., ed. 1984. Compendium of Strawberry Diseases. American Phytopathological Society, St. Paul, MN.

6. Madden, L. V. 1992. Rainfall and the dispersal of fungal spores. Adv. Plant Pathol. 8:39-79.

7. Madden, L. V., and Ellis, M. A. 1990. Effect of ground cover on splash dispersal of Phy tophthora cactorum from strawberry fruits. J. Phytopathol. 129:170-174.

8. Madden, L. V., Ellis, M. A., Grove, G. G., Reynolds, K. M., and Wilson, L. L. 1991 Epidemiology and control of leather rot of strawberries. Plant Dis.75:439-446.

9. Reynolds, K. M., Ellis, M. A., and Madden, L. V. 1987. Progress in development of a strawberry leather rot forecasting system. Adv. Strawberry Prod. 6:18-22.

10. Reynolds, K. M., Madden, L. V., and Ellis, M. A. 1988. Effect of weather variables on strawberry leather rot epidemics. Phytopathology 78:822-827.

11. Ristaino, J. B., Parra, G., and Campbell, C. L. 1997. Suppression of Phytophthora blight of bell pepper by a no-till cover crop. Phytopathology 87:242-249.

12. Rose, D. H. 1924. Leather rot of strawberries. J. Agric. Res. 28:357-376.

13. Seemüller, E. 1982. Versuche zur Bekämpfung der Rhizomfäule der Erdbeere mit Metalaxyl und Aluminiumfosetyl. Nachrichtenbl. Dtsch. Pflanzenschutzdienstes (Braunschweig) 34:118-122.

14. Seemüller, E., and Schmidle, A. 1979. Ein-

Table 3. Effect of fungicides and straw mulch on control of strawberry leather rot, 1995

\begin{tabular}{|c|c|c|c|c|c|}
\hline Treatment $^{v}$ & Rate (a.i./ha) & Timing & Leather rot $(\%)^{\mathrm{w}}$ & Marketable fruit $(\%)^{x}$ & Total yield $(\mathbf{k g})^{\mathrm{y}}$ \\
\hline Fosetyl-Al & $2.24 \mathrm{~kg}$ & $\begin{array}{r}\text { Start } 10 \% \text { bloom then } 7 \text {-day } \\
\text { interval }(17,23,31 \text { May })\end{array}$ & $2.8 c^{z}$ & $92.1 \mathrm{~b}$ & $4.2 \mathrm{a}$ \\
\hline Metalaxyl & $1.17 \mathrm{~kg}$ & Prebloom drench (26 April) & $1.3 \mathrm{c}$ & $94.6 \mathrm{ab}$ & $4.3 \mathrm{a}$ \\
\hline Metalaxyl & $1.17 \mathrm{~kg}$ & Drench late bloom (29 May) & $13.1 \mathrm{~b}$ & $84.2 \mathrm{c}$ & $4.3 \mathrm{a}$ \\
\hline Straw mulch only & & & $0.8 \mathrm{c}$ & $95.9 \mathrm{a}$ & $4.4 \mathrm{a}$ \\
\hline Untreated control & & & $72.6 \mathrm{a}$ & $23.9 \mathrm{~d}$ & $2.6 \mathrm{~b}$ \\
\hline Least significant difference (LSD) & & & 3.6 & 3.7 & 0.6 \\
\hline
\end{tabular}

${ }^{\mathrm{v}}$ Fosetyl-Al applied as Aliette 80WDG and metalaxyl applied as Ridomil 2E, according to methods described in text.

${ }^{w}$ Mean percentage of Phytophthora cactorum-infected fruit from three harvest dates (13, 16, and 21 June).

${ }^{x}$ Mean percentage of marketable fruit from the above three harvest dates.

y Total yield from the above three harvest dates.

${ }^{z}$ Numbers followed by the same letter within columns do not differ significantly according to Duncan's modified $($ Bayesian $)$ LSD test $(P=0.05)$. 
fluss der Herkunft von Phytophthora cactorum-Isolaten auf ihre Virulenz an Apfelrinde, Erdbeerrhizomen und Erdbeerfrüchten. Phytopathol. Z. 94:218-225.

15. Staub, T. 1991. Fungicide resistance: Practical experience with antiresistance strategies and the role of integrated use. Annu. Rev. Phyto- pathol. 29:421-442.

16. Wilcox, W. F., and Seem, R. C. 1994. Relationships between strawberry gray mold incidence, environmental variables, and fungicide applications during different periods of the fruiting season. Phytopathology 84:264-270.
17. Wright, W. R., Beraha, L., and Smith, M. A 1964. Leather rot in Louisiana strawberries on the Chicago market in 1974. Plant Dis. Rep. 48:747-748.

18. Wright, W. R., Beraha, L., and Smith, M. A 1966. Leather rot on California strawberries. Plant Dis. Rep. 50:283-287. 